the existence of this, except as the extra-systole of an arrhythmia, I have never been able to convince myself. I confess, therefore, Sir, with every desire to give full weight to the objections arged against the explanation of this sign given in my paper by so skilled an observer as Dr. Leonard Guthrie, that I still venture to maintain the possibility of an audible yet unregistrable ventricular extra-systole constituting the second note in the apical triple rhythm.

I am, Sir, yours faithfully, ALEXANDER MORISON.

Upper Berkeley-street, W., Oct. 16th, 1910.

\section{OPERATIONS AND MORTALITY.}

\section{To the Editor of THE LANCET.}

Sir,-A careful perusal of your leading article in THE LANCET of Oct. 15th leads to the conclusion that in your opinion under no circumstances is it advisable that an inquiry of any kind should be made after any fatal operation. You say, "There are ever those who are ready to cry unjustifiable when some new operation is proposed or performed." On Oct. Ist last, however, yon also say in a leading article on Fashion in Surgery : "There is, however, no little risk that in becoming accustomed as we are to a rapid progress in our ideas and methods we may from time to time mistake mere change for progress, the mere introduction of a new method for true advancement, a chance which is certainly increased by the fact that many procedures in surgery hold a place in our technique for a very brief period." Now, I agree in its entirety with these remarks of yours, which you further illustrate by reference to Sir James Simpson's method of arresting hæmorrhage by acupuncture, which you rightly say is now "absolutely forgotten." You also mention Calot's method of forcible reduction of angular curvature of the spine, the wonders of which " were proclaimed in nearly every medical periodical," but you further say, "Where is Calot's method now?" "Dangers undreamed of, or unmentioned, at the time soon made their appearance." "A few sudden deaths occurred and the promised improvement in the power of walking never materialised."

I would respectfully ask you, Sir, Do you not think that, say, one or two inquirics into the cause of death in some of these fatal cases would have been proper and to the benefit of the public at large? Not with a view to casting obloquy on an honoured profession, but with a view to the safety of the public and to bring about a discontinuance of a dangerous, and even fatal, operation.

Again, you further on in the same article state that: "In even more recent times still we have had gastro-enterostomy put forward as a panacea for all the ills that the stomach is heir to; for pyloric stenosis, both functional and organic for ulcer of the stomach and duodenum ; for hæmatemesis; for dilatation of the stomach, both with and without pyloric stenosis ; for malignant, as well as for simple, affections of the stomach." You then go on to say in most pregnant language: "Time, which tests all our inventions, has shown that this operation does not possess all the powers attributed to it, and at the present day probably the majirity of surgeons will agree that gastro-enterostomy is seldom of permanent value unless there is definite obstruction at the pyloric opening." Surely, after this scathing criticism of the operation of gastro-enterostomy, even you would admit that there was at any rate prim $\hat{\alpha}$ facie evidence that, in case of a fatal termination after this operation had been performed, say for gastric ulcer or spasmodic obstruction of the pylorus, there was a reasonable ground for an inquiry, even by a coroner's jury, and that no surgeon should undertake the operation unless he was quite prepared to face an inquest.

In your article of Oct. 15th you say: "Nothing would tend to stem the onward progress of surgery so much as to make a surgeon liable to have his work tried before a coroner's jury." From this proposition I entirely dissent, and to any careful reader of your article on "Fashion in Surgery," already alluded to, it must seem clear that some such con. trolling influence is required to prevent what we all know is so prevalent: that as soon as any surgeon introduces a new operation a host of imitators arise, and to the great disaster of progressive surgery numerous fatalities occur, due either to the initial unsoundness of the operation, or, in other cases, to the faulty technique of the unskilful imitator.

One more quotation from the same article. You say: "We cannot imagine a tribunal less fitted for deciding questions as to the desirability of an operation, or the capability of a surgeon, than a coroner's jury." In this you are at issue with most eminent members of the legal profession. Henry Edwin Fenn, senior reporter to the Law Courts, in his work on "Thirty-five Years in the Divorce Court," p. 208, says : "Juries are generally right, often more so indeed than judges and counsel, because they judge from a commonsense point of view." Sir Edward Carson, K.C., p. 213, said: "As a rule, juries return good verdicts. I should prefer a jury's verdict to that of a judge." Chief Justice Eve, p. 214, remarked: "A jury is in general far more likely to come to a right decision than a judge." Lord Halsbury says : "As a rule, juries are, in my opinion, more generally right than judges." Lord Russell of Killowen, p. 214, "held a very strong opinion on the value of a jury as judges of matter of fact. He always thought that the average opinion of twelve men of commonsense was at least equal to the judgment of twelve judges on matters of fact."

Provided you have no objection, Sir, I would respectfully ask you to state explicitly that under no circumstances do you consider it advisable that a fatal case after operation should be the subject of an inquiry? If you would not go so far as that, will you state under what circumstances you would consider an inquiry necessary? and, as you object to juries, what tribunal you would suggest as an equitable and proper one for the purpose? This question is coming rapidly to the front and the medical faculty may as well at once make up their minds to face it. Personally, my own opinion on the matter is simple. The present coroner's inquest is all that is needed: the ordinary jury is quite able to adjudicate on the matter. If no operation were undertaken, involving ang particular risk, without a deliberate consultation beforehand, with one at least, but preferably two, experienced practitioners, no operator need fear an adverse verdict of the jury in case of a fatal termination. The coroner should have the power, after considering the details of the case furnished to him, to determine as to the advisability of holding an inquest or not. This would at once prevent the holding of needless and vexatious inquests. More than this, I am of the opinion that if the people at large knew that these precautions were taken, they would more cheerfully and volun. tarily resign themselves to the surgeon's hands, confident that no merely experimental operations would be undertaken, but only such as were for the undoubted benefit of the patients themselves. I am, Sir, yours faithfully,

Preston, Oct. 17th, 1910.

JAMES A. RIGBY

** In the leading article of Oct. 15th we purposely alluded to the previous article of Oct. 1st. The disuse into which a new and wrong procedure falls is quite rapid, while the tendency of the compulsory inquest would be to prevent any new and right procedure ever being tried. Certainly we do not say that in no case would an inquest be justifiable where an operation had been fatal. Nor have we said that we "object to juries," but only that a coroner's jury is an unfit tribunal to sit in judgment upon surgical methods and results. - ED. L.

\section{EFFICIENT VENTILATION}

\section{To the Editor of THE LANCET.}

SIR,-I am glad to see Dr. Leonard Hill dirawing attention to the important fact first brought out by the classical experiments of Professor Flügge and his pupils Paul, Heymann, and Ercklent $z,{ }^{2}$ by Dr. Haldane, ${ }^{2}$ and confirmed by himself-namely, that the unpleasant sensation of "stuffiness" or "closeness" induced by air of an occupied room in which the ventilation is imperfect is due to heat retention. I should like to see our sanitary authorities making practical application of this discovery for the benefit of the public health, and apparatus recording the wet bulb temperature of the air in use in all theatres and public places of assembly, such apparatus submitted to regular inspection, and a fine imposed when the wet bulb temperature of the air during occupation exceeds the limit compatible with comfor and health. Why should one be incubated when at the theatre?

1 Zeitschrift fur Hygiene, Band xlix, 1905. 2 Journal of Hygiene. 1905. 